\title{
SRESS REDUCTION PROGRAMME STRAIMY AND BIOFEEDBACK MEASUREMENT SYSTEM ADAPTION IN RIGA TEACHER TRAINING AND EDUCATIONAL MANAGEMENT ACADEMY
}

\section{SUMMARY}

Introduction. The research is based on Project "Biofeedback system in adapting process of STRAIMY and EMYK from Leipzig University to RTTEMA Professional master programme in psychology" results in 2008.

Aim of the Study. To experimentally study the indicators of the biological reciprocal link with Biofeedback test system in five experimental groups for adapting prof. M. Stueck's (Leipzig University) programme for stress reduction.

Materials and Methods. BIOFEEDBACK 2000 EXPERT tests measurement system, BESTATStatistical Evaluation Module and observation and interview method. Two treatment methods have been used: trainer's self-report method with content analysis and participants 'self-report method with content-analysis.

Results. Programme STRAIMY (Stressreduktionstraiming mit Yogaelementen fuer Erwachsene STRAIMY®”, developed by Marcus Stueck) is suitable and can be applied on Latvian adult population in RTTEMA master programmes. BOFEEDBACK 200 Expert and BESTAT are adequately operationalised in experimental groups.

Conclusions. Qualitatively summarised statements expressed by the participants in Latvian experimental groups after attending STRAIMY® course indicate an explicit cognitive behavioural activity of participants as to stress self-management and related themes that strongly affect the previous stereotypic thinking models.

Key words: BIOFEEDBACK 2000 EXPERT tests measurement system, BESTAT- Statistical Evaluation Module

\section{INTRODUCTION}

Stress decreasing programme STRAIMY (Stressreduktionstraiming mit Yogaelementen fuer Erwachsene STRAIMY ${ }^{\circledR}$ ", developed by Marcus Stueck), which is formed on the basis of researches and habilitation work of professor M. Stueck of Leipzig University, was adapted for the inhabitants of Latvia initially for three and afterwards for two groups of Latvian respondents comprised of representatives of supporting professions (teachers, psychologists, social workers, officials). During the project, statistical data processing programme BESTAT for Biofeedback measuring data was acquired. During the implementation of the programme, one multiplier was prepared for acquisition of the programme methodology and contents; psychometric analysis of the received data was carried out by using the system attachment of the newly acquired BESTAT- Statistical Evaluation Module. Likewise additional tasks were carried out: compliance of the Latvian translation with the perception of representatives of the five groups of Latvian population was examined; researches by M. Stueck and other authors on stress and possibilities of yoga (including autogenous training and meditation) 
in stress self-management have been theory-wise analysed; qualitative analysis of the process of the respondents in the Latvian experimental group during acquisition of STRAIMY® programme was carried out by using the following methods: observation, interviews and content-analysis.

There are hundreds of researches done to assess the impact of stress self-management exercises on the changes indicating physiological stress (function of the heart, frequency of breathing, indicators of relaxation, sleep quality, emotional states, etc.). Below there are several results that have been used for this research confirming the impact of yoga exercises on self-regulation of stress that have been used in STRAIMY programme:

- P. Unger and D. Hoffman (Unger, 1984; Hoffman, 1994) have proved through experiments that the participants in the experiment described breathing as a possibility to "relax, calm down and concentrate",

- M. E. Hardt (Hardt, 1977) has carried out research using EEG indicators, when the participants were asked to do slow and deep diaphragm breathing exercises, and most often it was alpha waves shown in EEG that are characteristic of a relaxed state,

- In research carried out in 1972 by the group of scientists comprised by J. M. Timmons, J. Salamy, T. Kamiya, P. Girdon (Timmons, 1996), it was proved with the help of EEG that during the activities where alpha waves dominated (in the state of relaxation) the participants in the experiment breathed with their diaphragms,

- In his turn, P. Harvey (Harvey, 1983) compared two experimental groups: the group that was practicing yoga breathing exercises when compared to the control group showed higher degrees in indicators proving the ability to relax as well as decreased depressiveness and fewer disturbances of sleep after one month's time. The researchers arrived at the conclusion that breathing exercises is a powerful mechanism of self-control which can help to deliberately stabilise and improve the indicators of emotional sensitivity,

- A. Ananda (Ananda, 1980) has proved that through practicing rhythmic breathing it is possible to treat psychic and psychosomatic illnesses: fear syndrome, depressive states, nervousness, headaches, hypotension, hypertension and bronchial asthma,

- P. L. Ebert (Ebert, 1991) characterises yoga exercises from the therapeutic point of view stating that they give an opportunity to renew disturbed inner balance and achieve homeostasis. This kind of a state is often interpreted as an ,inner balance and harmony of a person”.

"Stress is important and necessary psychological and physiological mechanism for human functioning that helps overcoming threatening situations." (Stueck, 2008) In psychology and thus also in this programme, a significance is vested in stress relation to emotions, accentuating the most important emotions which in case of their non-cessation threaten a person's psychic and physical health. These emotions are continued and insuperable fear, depressiveness, anger and constant change of hope and resignation. Within the scope of stress self-management programme, the link between stress and emotions is revealed and analysed emphasizing the role of autonomous or the vegetative system (ANS) in stress regulation.

In work with stress management programme, such themes are reviewed that relate to the following indicators of emotional burn-out: syndrome of burn-out, psychosomatic symptoms and physical illness, stereotype, blood-pressure, food, anger, conflicts, social competence, delight, life time, time planning, formulating aims and others.

The practical part of STRAIMY programme provides a possibility to learn stress selfregulation methods by using one's body - yoga, breathing exercises, and meditation. When adapting 
any programme, it is important to plan experimental criteria that correspond to the goal. In order to determine the scientific compliance of the adaptation of a programme, a part of those criteria that were used by the author of the research programme was also utilised here, that is, the galvanic resistance of skin or the electro-dermal activity (EDA) as indicator of stress level, measure of pulse, density of blood flow, warmth or change of body temperature as a result of meditations and breathing exercises. STRAIMY programme works with prevention of stress in the first phase of dealing with it when a person can learn techniques for cognitive self-management, as well as with the second phase when stress has already affected emotions and psycho-physiological (biochemical) reactions of the body associated with them such as blood pressure fluctuations, tension of muscles, disorders of function of the heart, peculiarities of skin temperature (lower temperature in case of stress) etc. that are characteristic indications.

STRAIMY programme works with cognitive self-management methods therefore in the beginning of every training discussion on the possible changes of impact of stressors is held. As the second phase involves learning the change system of vegetative body reactions, the second part of the training is devoted to modified yoga class exercises (which is a peculiarity of this STRAIMY programme) involving breathing, muscle relaxation, meditation (visualisation) practice. Specialists work with overload regarding it a consequence from a stressor. That is why this programme has been devised selecting teachers as the source group. Additionally, stressors connected with a cognitively created idea on the responsibility of an individual towards himself and work, as well as the consequences originating from a lasting exhaustion.

\section{AIM OF THE STUDY}

To experimentally study the indicators of the biological reciprocal link with Bio- feedback tests system (BVP (Blood Volume Pulse), PVA (Blood Volume Amplitude), PULS (Pulse rate): EDA (ElectroDermalActivity), SCL (SkinConductanceLevel), SCR (SkinConductanceReflex) in five experimental groups for adapting prof. M. Stueck (Leipzig University) programme for stress reduction.

\section{MATERIALS AND METHODS}

M. Stueck's programme was adapted after RTTEMA student Tija Kazāka translated and examined during studies at Leipzig University within the scope of Erasmus programme. At first, this programme was acquired within the scope of RTTEMA focus-group. This was done by managers and participants of the research with M. Stueck and T. Kazāka's participation at RTTEMA seminars in 2008. The measuring instrument BIOFEEDBACK 2000 Expert and mathematically statistical data processing programme BESTAT, which was purchased by funds provided for the project, was used as material and method. Quality methodology was used for data analysis - the content-units gathered during various interviews between group participants and the leader of the experimental groups, this allowed to judge about adequate evaluation of stress management method STRAIMY together with indicators of biological reciprocal link.

Globally, most often the measures of electro-dermal activity (EDA) are used for determining a level of psychic excitement or diagnosing the level of stress and relaxation. Physiologically, EDA activity is related to the activity of sweat gland secretion whose level is determined by processes in cortex (mental activity, cognition, consciousness) and limbic system (centre of emotion control in the brain). Further on, the intensity of sweat secretion is intervened by ANS simpatic or excitation part). EDA is a good parameter for determining the level of human stress - relaxation and vegetative activity.

The level of EDA is determined in the researches performed by Stueck and his colleagues by using measuring instrument HIMEN which is developed by Hecht \& Balzer and which the 
participants can carry up to 24 hours in order to acquire data on the long-term effect of stress selfregulation methods focused on the body.

Likewise vegetative tonus point is also researched (VTP). Upon describing and analysing researches on stress and possibilities of its self-regulation, it is important to draw special attention to such parameter as VTP. This parameter was also analysed by Stueck within the framework of the STRAIMY ${ }^{\circledR}$ training. VTP is a point of the vegetative tonus (or - ANS activity/rest) where a person is in a state of stress or rest. When the stress level in a body is increasing, this point is drawn to ANS simpatic or excitement pole. When the organism returns to the state of rest, VTP is directed to para-simpatic or the rest pole. A schematic picture of this conditional point can be seen in the Image below. In the practical part of the training, attention is drawn to the possibility of selfregulation of this point, and, using "breathing with diaphragm" in stress situation, the VTP can be moved to the side of ANS para-simpatic pole.

Significance and efficiency of breathing in STRAIMY® training.

Breathing exercises form a significant part of in yoga and thus also of STRAIMY® training, which as meditation component and stress self-management method, is practised also outside yoga classes. Breathing in yoga is used as a means that join body and psyche. Exercising to breathe knowingly, a yoga practitioner can learn to knowingly direct his emotions, that is, to influence his ANS. Exhalation takes place "through stomach", that is - with the diaphragm. It is impossible to reach a state of relaxing when breathing with "chest". By practicing breathing techniques that help extending the exhalation it is possible to relax tension in the body and psyche (Stueck, 2006 - 2008).

By aware control of inhalation and exhalation it is possible to manage the following ANS processes:

a) By breathing slowly and deeply, the simpatic ANS part is activated to prepare the body for overcoming load. Thus muscle tone is increased, pulse is accelerating and blood pressure is increasing (VTP moves to the stress pole).

b) By breathing slowly and at length, the para-simpatic part of ANS is stimulated. As was proved by J. Klingenberg, by controlling breathing in stress situation, pulse is slowing down, blood pressure falls, peripheral blood-vessels are enlarged, muscle tone is relaxing (relaxation). M. Jahn proved that by knowingly managed long exhalations, it is possible to decrease the state of tension and excitement quickly and efficiently (Stueck, 2008).

\section{Breathing and ANS dysfunction.}

ANS dysfunction is caused by shallow breath (only in the upper part of the chest). Cause of vegetative dysfunction or dystonia is shallow breath. Short and shallow breath is related to neurasthenia, psychastenia and general emotional lability which result in various psychosomatic symptoms. In order to heal or influence ANS dysfunction and the psychosomatic illnesses subjected to it, various breathing techniques are acquired in yoga (including STRAIMY®) practice helping to learn breathing deeper and more slowly - with diaphragm. When breathing becomes deeper and especially - when exhalation is extended, general body muscle tone relaxes, which is directly related to the tension caused by stress accumulated in the body. When muscle tone relaxes, likewise psychiatric tension relaxes.

In 1986, German scientist R. Ebert (cited in Kazāka, Svence, 2008) carried out a study on psycho-physiological aspects of yoga, but M. Benson (cited in Stueck, Villegas, Perche, Balzer, 2008) researched the relaxation efficiency of autogeneous training. Results of these researches proved that any state or relaxation is caused by psychic phenomenon as passive concentration when 
being awake. Resulting from this fact, the Picture 1. Psycho-physiological triad (Kazāka, so called psycho-physiologic triad was developed (see Picture 1). By passively concentrating on one's breathing, a "switch" takes place in a person's vegetative neural system which was described by AT creator

R. Schultz in 1936 (cited in Hecht, Andler, Breinl, Landler, 2006). This is expressed in a way that breathing frequency is slowing down, muscle and vegetative tone is relaxing. Reaction of relaxing takes place and vice versa - relaxing of vegetative and motoric tone increases the level of passive

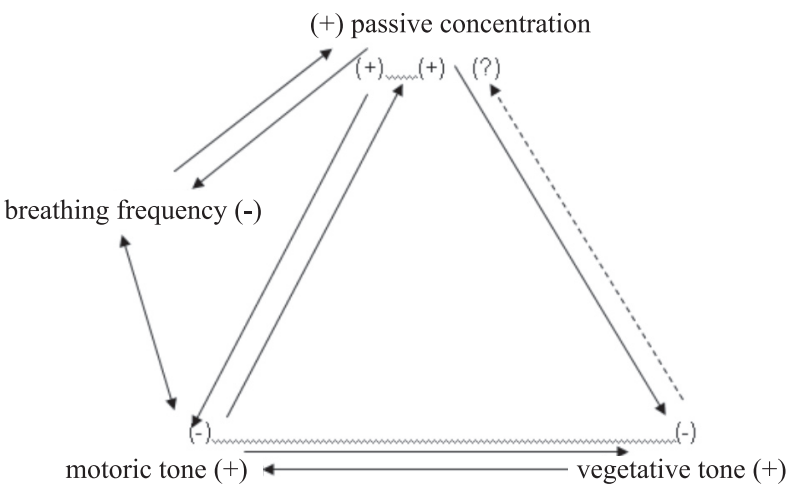
concentration. Stueck stresses that causal relation of the mentioned phenomena has not still been explained (Stueck, 2008).

A group of scientists in Wisconsin University (USA, Madison) have studied the positive effect of meditation on the system of immunity and brain activity. The group with Richard Davidson as the head carried out a research where its participants had to intensively concentrate on thoughts and emotions of the specific moment excluding any evaluation (attention meditation). Twenty-five participants took part at the research and worked at a meditation group for eight weeks as well as meditated at home. There were sixteen people in the control group who did not meditate.

At the end of the research, the participants' brain activity was measured. In accordance with the above-mentioned researches, confirming that the activity of the left brain hemisphere is related with positive emotions, likewise the activity of left brain hemisphere of members meditating in this research was more pronounced than the activity of the members of the control group (Davidson, 2003).

After this research its participants were injected influenza virus vaccine, and in four and eight weeks, development of influenza antibodies in participants' organism was measured. Although antibodies were developed in organisms of participants from both groups; however, meditating participants had the antibodies developed significantly more.

Results of these researches allow concluding that meditation is an efficient means for stress self-management because activity of the immune system is directly related to stress level in the organism.

\section{STRAIMY® concept and efficiency}

STRAIMY ${ }^{\circledR}$ concept and efficiency has been studied in various projects and diploma papers and results of the studies have been summarised in Stueck's habilitation work which was worked out from 1999 to 2007.

In Leipzig, a study was carried out on STRAIMY® efficiency for teachers (Stueck, Rigotti, Mohr, 2004).

The study took six months (in practice, the training took place in ten weeks, two hours once per week). Measures were taken before and right after the training course, as well as in six months. Forty teachers in twenty-two experimental groups (average age 43.64) and in eighteen control groups (average age 45.83) participated in the study. Participants of the experimental groups took part in the STRAIMY® programme for a time period of ten consecutive weeks, one time per week, two hours. In order to find out whether this training helps improving stress self-management skills (internal and 
external coping), a set of instruments was found so that it would be possible to measure the changes of reactions caused by cognitive and emotional stress, effect of relaxing and training on feeling of comfort and health. These parameters were acquired pursuant to the results of questionnaires of tension (stress) managing analysis by E. Richter, A. Rudolf and M. Schmidt (Richter, Rudolf und Schmidt Fragebogen zur Analyse belastungsreleventer Anforderungsbewaeltigung) (cited in Kazāka, Svence, 2008). Data acquired during the study confirmed the efficiency of this training as relaxation method. Results showed improvement of psychological (feeling of comfort, ability to relax), physiological (relaxing effect, skin sensitivity, pulse) and immunological (immunoglobulin A) of teachers involved in the study.

An instant and long-lasting decrease of consequences caused by stress was detected in the sense of a more successful functioning of a personality (communication models in working environment, self-efficiency, ability to regulate emotions, control of anger improved).

Study on immunological changes of participants of STRAIMY® training (Stueck, Meyer, Rigotti, Bauer, Sack, 2003; Stueck, 2008).

Eleven teachers whose average age was 41.6 participated at the study. The subjective relaxation feeling of the participants was measured according to the 17-point scale of B. Binz \& J.Wend (Binz, Wend, 1986, cited in Kazāka, Svence, 2008), as well as the level of immunoglobulin A (IgA) before and after each training session. The level of IgA can be detected in saliva and it serves as parameter of protection skills of the immune system. Weakening of the immune system is directly related to the increased level of stress that is the cause for various psychosomatic illnesses.

After the sixth to the tenth STRAIMY ${ }^{\circledR}$ training session, a significant increase of the level of IgA in the participants' saliva was detected. This means an increase in the participants' immune system protection abilities. The participants' subjective relaxation feeling was significantly increased after the eighth and tenth STRAIMY® session.

Systolic blood pressure as stress indicator.

Blood pressure, especially the systolic pressure is figuratively called "seismograph of the soul". It is possible to prove by researches that stimuli of negative thoughts (and afterwards - emotions) increase blood pressure. Participants of the study had the changes of heart frequency and blood pressures measured by biofeedback equipment.

Results of the study showed that in cases when a person thinks of something negative and worrying the systolic blood pressure increases, but at the relaxation phase it decreases.

\section{RESULTS}

There were three activities performed: STRAIMY® adaptation in the work of pilot study group, the first trial and studying of the bio-feedback programme. Initially in the work with bio-feedback, mistakes were made which were related to time and skills needed for programme acquisition. For example, measures were not taken during the whole session, rather only for some minutes (measure time was not set correctly in computer). Work in this group should be regarded as a good preparation for the first experimental group, which worked at the Psychology Faculty of the RTTEMA. The pilot study group acquired valuable measures which already proved the efficiency of STRAIMY® in the Latvian population. As well as the experience of group management and an insight was acquired on what space and circumstances would serve best for organising work of such a group. This is, group work needs an empty, warm, and quiet room where no noises enter from the street, and no passers-by can come in by accident. These requirements are especially related to the deep relaxation - meditation - the part of the autogenous training where complete silence is necessary. Likewise warmth is an obligatory precondition so that the participants could fully relax. 
Measures were made by BIOFEEDBACK 2000 Expert system. As the variant purchased by the RTTEMA had only one sensor, it is physically not possible to measure many participants at once; therefore the sensor was attached to the hand of only one person to be studied during each session (see Picture 2).

Picture 2. Example on BIOFEEDBACK measure in the first session

Diagram: Session2

Date / Time: 14.03.2008/13:55

Measurement way: Lines (multi-feedback)
Duration of session: $00: 44: 18$

Display: $\quad 00: 00: 00$.. 00:44:18
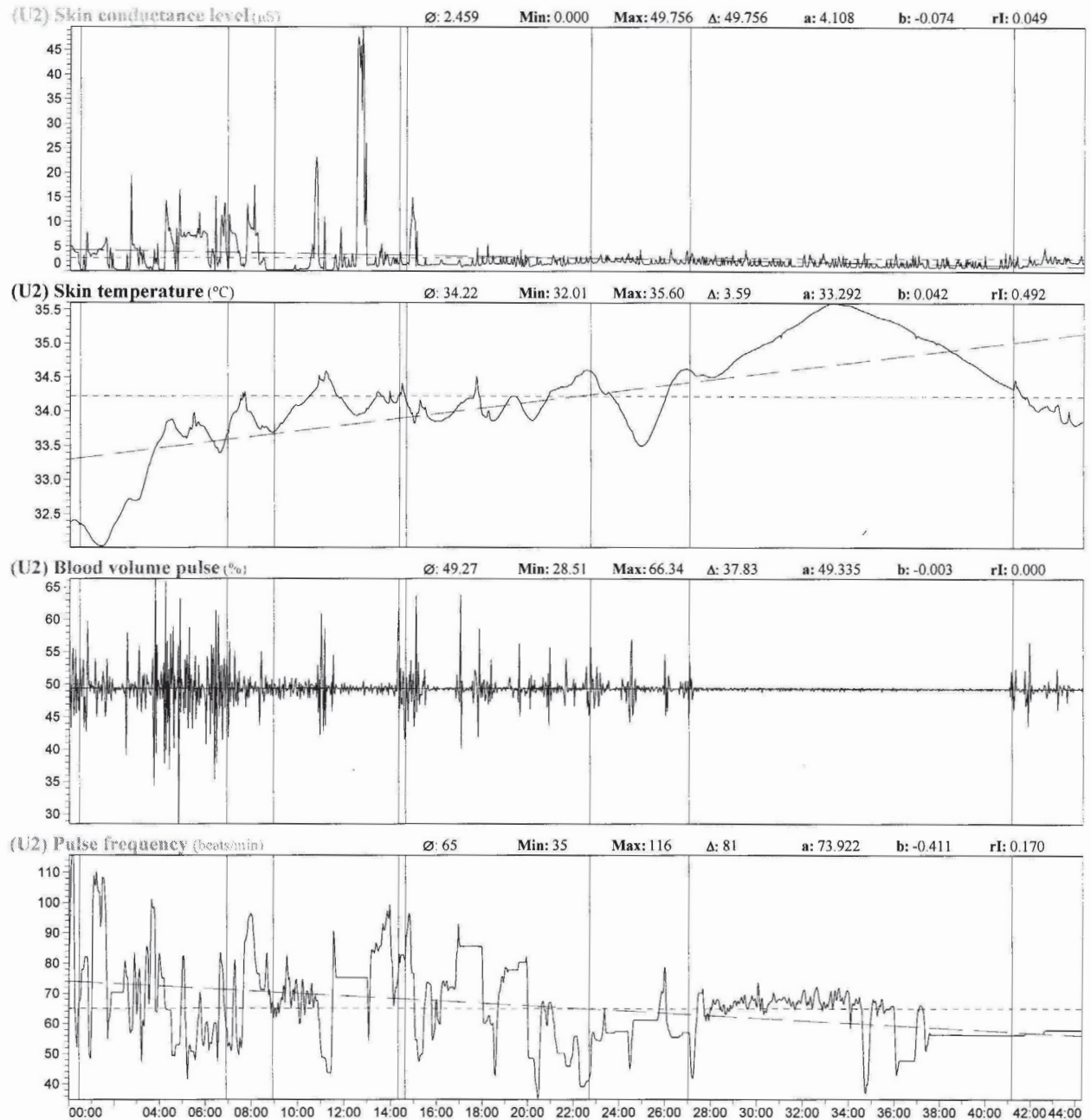

1. 00:00:00.000 BG $>$ Color

2. 00:00:26.734 joga

3. 00:06:54.344 Device <U2>: Communication between the computer and module does not appear to be functioning correctly. \{No. 31/

4. 00:08:53.172 joga gulus

5. 00:14:18.390 Device <U2>: Communication between the computer and module does not appear to be functioning correctly. \{No. $31 /$

6. 00:14:37.640 Device $<\mathrm{U} 2>$ : Communication between the computer and module does not appear to be functioning correctly. \{No. 31 \}

7. 00:22:41.484 telefons zvana

8. $00: 27: 00.984$ AT

9. 00:41:08.734 celas no meditacijas

\section{Biofeedback 2000x-pert}

Copyright (c) $1999-2007$ Schuhfried $\mathrm{GmbH}$ 
Measures proved an instant change of psycho-physiological parameters in the participant's organism during the deep relaxation or meditation, when reviewed according to criteria offered by Biofeedback - increase of skin warmth begun when meditation had started, the pulse decreased, indicators that refer to the galvanic resistance of skin were levelled.

During observations and interviews in all experimental groups, data was acquired and summarised on the participants' emotional, cognitively behavioural and psycho-physiological selfregulation during acquisition of STRAIMY ${ }^{\circledR}$ programme. For acquisition and analysis of data, qualitative research methods were used - observation, interview (in group process) and content analysis (see Table 1).

Table 1. Units of behaviour and content (expressions/reaction) of participants of experimental groups during STRAIMY® training according to the frequency

\begin{tabular}{|c|c|c|}
\hline STRAIMY ${ }^{\circledR}$ task & Behaviour of the participants & $\begin{array}{l}\text { Expressions of the participants - reactions to } \\
\text { the given task }\end{array}$ \\
\hline 1. Autogeneous training & $\begin{array}{l}\text { Participants get readily involved. } \\
\text { Participants relax better when lying } \\
\text { down, not sitting. }\end{array}$ & $\begin{array}{l}\text { - I can easily make the feeling of warmth in } \\
\text { my hands. } \\
\text { - I need to relax in the beginning of the } \\
\text { session. }\end{array}$ \\
\hline $\begin{array}{l}\text { 2. The first round (how I } \\
\text { feel, what I have learnt, what } \\
\text { I want to say) }\end{array}$ & $\begin{array}{l}\text { Participants readily talk, tell about } \\
\text { stress in their lives. }\end{array}$ & $\begin{array}{l}\text { - I cannot manage stress in my life on my } \\
\text { own. } \\
\text { - My body suffers from my stress. } \\
\text { - I need a place where I can relax. }\end{array}$ \\
\hline $\begin{array}{l}\text { 3. Psychologically educating } \\
\text { part }\end{array}$ & $\begin{array}{l}\text { Participants actively follow, ask } \\
\text { questions, immediately ask again about } \\
\text { the items they did not understand, give } \\
\text { examples from life. }\end{array}$ & $\begin{array}{l}\text { - Things about stress, which were known } \\
\text { long ago, have been forgotten. } \\
\text { - It should be repeated in order not to } \\
\text { forget. } \\
\text { - Several theory items are a novelty to me. }\end{array}$ \\
\hline $\begin{array}{l}\text { 4. Filling in handouts - tests, } \\
\text { exercises }\end{array}$ & $\begin{array}{l}\text { Participants actively and with interest } \\
\text { fill in tests and self-analysis materials. }\end{array}$ & $\begin{array}{l}\text { All the burn-out syndrome indicators } \\
\text { correspond to me. } \\
\text { The test shows my overload level. }\end{array}$ \\
\hline 5. Training in pairs & $\begin{array}{l}\text { Participants do not willingly take part } \\
\text { in pair-trainings. }\end{array}$ & $\begin{array}{l}\text { I don't like training in pairs. } \\
\text { Can we skip these exercises? }\end{array}$ \\
\hline 6. Group discussion & $\begin{array}{l}\text { Participants discuss very actively, tell } \\
\text { about their stress and experience. }\end{array}$ & $\begin{array}{l}\text { Participants' examples on stress situations } \\
\text { that correspond to the reviewed theory } \\
\text { material of STRAIMY®. }\end{array}$ \\
\hline 7. Yoga & $\begin{array}{l}\text { Participants get involved readily and } \\
\text { with interest. Some participants find } \\
\text { certain poses difficult by manageable. }\end{array}$ & $\begin{array}{l}\text { - In childhood, I did it without difficulties. } \\
\text { - It is nice to exercise again. }\end{array}$ \\
\hline 8. Breathing exercises & $\begin{array}{l}\text { Participants do the exercises readily } \\
\text { and with interest. }\end{array}$ & $\begin{array}{l}\text { - I did not know that there are so many } \\
\text { ways of breathing. }\end{array}$ \\
\hline $\begin{array}{l}\text { 9. Deep relaxation/ } \\
\text { meditation }\end{array}$ & $\begin{array}{l}\text { Participants get involved with extreme } \\
\text { interest, readily. }\end{array}$ & $\begin{array}{l}\text { - I "switch off" immediately. } \\
\text { - I "switch off" and fly somewhere. }\end{array}$ \\
\hline $\begin{array}{l}\text { 10. Meditation when } \\
\text { walking }\end{array}$ & $\begin{array}{l}\text { Participants start the exercises } \\
\text { reservedly, with interest, but do them } \\
\text { willingly. Some stand aside for a while, } \\
\text { observe the situation. }\end{array}$ & $\begin{array}{l}\text { - It is very difficult not to think anything. } \\
\text { - This exercise is difficult but I would like } \\
\text { to use it in everyday-life. }\end{array}$ \\
\hline $\begin{array}{l}\text { 11. The closing round (how I } \\
\text { feel, what I want to say) }\end{array}$ & $\begin{array}{l}\text { Participants have relaxed, calm, readily } \\
\text { share with others on how they feel. }\end{array}$ & $\begin{array}{l}\text { Data summarised in a table on STRAIMY }{ } \\
\text { efficiency in Latvian groups. }\end{array}$ \\
\hline
\end{tabular}




\section{CONCLUSIONS}

Qualitatively summarised expressions of participants from Latvian experimental groups after attending STRAIMY ${ }^{\circledR}$ course indicate a pronounced cognitive behavioural activity of participants in the aspect of stress self-management and related themes that strongly affect the previous stereotypic thinking models. The practical STRAIMY ${ }^{\circledR}$ part is distinctive because of formation of new awareness of one's body and para-simpatic stimulation of ANS. As a result of both these STRAIMY ${ }^{\circledR}$ parts, a new awareness of unity of body and psyche is formed.

\section{REFERENCES}

1. Ananda, A. (1980) Relations among Gender, Violence Exposure, and Mental Health: The National Survey of Adolescents, http://www.apa.org/psycinfo/ (30.01.2009.).

2. Davidson, R. (2003) Studie: Meditation hat positive Effekte auf Immunsystem und Gehirn [Study: Meditation has Positive Effects on Immune System and Brain]. http://www.wissenschaft.de/ wissenschaft/news/203377.html. (01.06.2008.) (in German).

3. Ebert, P. L. (1991) Recollection- and Familiarity-Based Memory of Healthy Aging and Amnestic Mild Cognitive Impairment. http://www.apa.org/psycinfo/ (30.01.2009.).

4. Hardt, M. E. (1971) Adaption to Disaplaced Vision: a Change in the Central Control of Sensorimotor Coordinator. Journal of Experimental psychology. Vol. 89, August, p. 229-239.

5. Harvey, S. (1983) Emotional Abuse in the Workplace. http://www.apa.org/psycinfo/ (30.01.2009.).

6. Hecht, H., Andler, S., Breinl, S., Lander, H. J., Stueck, M. (2006) Objektive Kontrolle der Selbstentspa nnungsfaehigkeit anhand von Zeitreihenmessungen des Blutdrucks und der Elektrodermalen Aktivitaet [Objective Control of Self-Relaxation Skills by Means of Time Measurements of Blood Pressure and Electro-Dermal Activity]. Seminar Materials at the Leipzig University (in German).

7. Hoffman, D. (1994) The Relationship between Person- Organisation Congruence, Perceived Violations of the Psychological contract, and Occupational Stress symptoms. http://www.apa.org/psycinfo/ (30.01.2009.).

8. Kazāka, T., Svence, G. (2008) Impact of Stress Self-management Trainings on the Feelings and Psychophysiological Indicators of Women from Various Groups. Rìga: RPIVA, p. 1-71.

9. Stueck, M. (2003) Integrative Belastungsbewaeltigung in der Schule [Integrative Coping Processes in School]. Das IBiS - Konzept. Praevention. Zeitschrift fuer Gesundheitsfoerderung [Journal for Health Promotion], 26 (4), S. 115-118 (in German).

10. Stueck, M. (2008) Raufkommen ist leicht, wie komme ich wieder runter [Coming up is Easy when I Come under Again]. Expedition zum Stressberg. Handbuch zum Stressreduktionstraiming mit Yogaelementen für Erwachsene STRAIMY ${ }^{\circledR}$ [Manual for Stress Reduction Training with Yoga Elements for Adults STRAIMY®]. Pilot Copy of the Book (in German).

11. Stueck, M., Hoernig, D., Hecht, K. (2001) Emotioneller Stress durch Ueberforderung und Unterforderung [Emotional Stress Due to Excessive Demands and Under-challenging]. Berlin, Milov: Schibri - Verlag, S. 215-250 (in German).

12. Stueck, M., Meyer, K., Rigotti, Th., Bauer, K., Sack, U. (2003) Evaluation of a Yoga - Based Stress Management Training for Teachers: Effects on Immunoglobulin A Secretion and Subjective Relaxation. Journal of Meditation and Meditation - Research, 2(1), p. 59-68. 
13. Stueck, M., Rigotti, Th., Mohr, G. (2004) Untersuchung der Wirksamkeit eines Belastungsbewaeltig ungstrainings fuer den Lehrerberuf [Research of Efficiency of Coping Process Training for Teacher Profession]. Psychologie in Erziehung und Unterricht [Psychology in Upbringing and Education], 51 (3), S. 236-245 (in German).

14. Stueck, M., Villegas, A., Perche, F., Balzer, H. U. (2007) Neue Wege zum Stressabau im Lehrerberuf: Biodanza und Yoga als Koerperorientierte verfehren zur reduktion psycho - vegetativer Spannungszustaende [New Ways to Stress Building in Teacher Profession: Biodanza and Yoga as BodyOrientated Methods for Reducing Psycho-Vegetative Tension State]. http://www.bildungsgesundheit. de/Stressabbau\%20Lehrer\%202007.pdf (01.06.2008.) (in German).

15. Timmons, J. M. (1996) Post-Traumatic Stress Symptoms in Mothers Following Children`s Reports of Sexual Abuse: an Exploratory Study. American Journal of Orthopsychiatry, 66 (3), July, http://www. apa.org/psycinfo/ (30.01.2009.).

16. Unger, D. G. (1984) Living near a Hazardous Waste Facility: Coping with Individual and Family Distress. American Journal of Orthopsychiatry, Vol. 62, http://www.apa.org/psycinfo/ (30.01.2009.).

Assistant Professor Dr. psych. Guna Svence

Researcher of Scientific Institute of Creativity, Dean of Faculty of Psychology

Riga Teacher Training and Educational Management Academy

Address: Imantas 7. līnija 1, Rīga, LV-1083

Phone: +37129106837

E-pasts: guna.svence@rpiva.lv

Bc. psych. Tija Kazāka

Graduate of Riga Teacher Training and Educational Management Academy

Sertified STRAIMY trainer

Address: Imantas 7. līnija 1, Rīga, LV-1083

Phone: +371 29106837

E-pasts: guna.svence@rpiva.lv 